\title{
Characteristics Analysis and Corrosion Inhibition in Typical Produced Water of Jidong Oilfield
}

\author{
Chen Dong ${ }^{1,2}$ \\ ${ }^{1}$ Tangshan Jiyou Ruifeng Chemical Co., Ltd, 063200, Tangshan, China \\ ${ }^{2}$ Hebie Oilfield Chemical Agent Technology Innovation Center, PetroChina Jidong Oil Field, 063200, Tangshan, China
}

\begin{abstract}
The composition of oilfield water is complex and diverse. The development and application of corrosion inhibitors can effectively inhibit the corrosion of pipelines and equipment by oilfield water. The ions in produced water of Jidong Oilfield were determined by instrumental analysis and chemical analysis. Triazine prepared from ethanolamine and formaldehyde as corrosion inhibitor was evaluated by weight loss method. The corrosion inhibition experiments were carried out in ancient water samples, and the effects of concentration and temperature on corrosion inhibition were investigated. Finally, corrosion inhibitors were applied to the corrosion inhibition of produced water with different compositions in Jidong Oilfield, the corrosion inhibition of steel sheet was evaluated under different salinity conditions, and the effects of various ion contents in typical water samples and salinity on corrosion inhibition were analyzed. The experimental results show that the corrosion inhibition effect of triazine is better, and the product can be used in various water samples in oilfield with the inhibition efficiency above $85 \%$.
\end{abstract}

Keywords: Corrosion inhibition; weight loss method; water analysis.

\section{Introduction}

In the process of oil and gas field oil production, the produced water is of poor quality and complex composition [1]. It generally has high salt content, high COD value, large polymer content, and large oil content $[2,3]$. Some also contain small amounts of heavy metals and bacteria [4]. Direct discharge will cause irreversible damage to the surrounding environment and a great waste of water resources. In oil and gas fields, it is generally considered to reinject the produced water after treatment [5]. If the water quality conditions do not meet the injection requirements, scaling, blockage, and corrosion will occur [6,7], which will inevitably cause corrosion on the oil layer [8], water injection pipelines and equipment [9]. In order to ensure that the water quality meets the technical requirements of the industry, oilfield water detection and analysis is required [10]. On the one hand, it can ensure that the water quality requirements for reinjection are met, and scaling and corrosion are reduced [11], and on the other hand, the recovery factor cannot be reduced [12]. In addition to using corrosion-resistant materials, corrosion inhibitors must be selected according to the specific water environment and added to the produced water [13]. However, research on the costeffective, low-toxicity and environmentally friendly corrosion inhibitors with high corrosion inhibition efficiency for steel is urgently needed [14-16]. As a new corrosion inhibitor, triazine, a synthetic product of ethanolamine and formaldehyde, has excellent corrosion inhibition properties. With the stable spatial structure and inhibitory properties [17,18], triazines are suitable for oilfield produced water containing complex ions.

\section{Experimental}

\subsection{Materials}

Ethanolamine was supplied from Tianjin Kermel Chemical Reagent Co., Ltd. Formaldehyde was purchased from Tianjin Tianli Chemical Reagent Co., Ltd. Anhydrous calcium chloride was purchased from Tianjin Shengao Chemical Reagent Co., Ltd. Magnesium chloride hexahydrate was supplied from Chengdu Kelong Chemical Reagent Factory. Sodium bicarbonate was purchased from Tianjin Baishi Chemical Co., Ltd. Anhydrous sodium sulfate was purchased from Tianjin Tianli Chemical Reagent Co., Ltd. Sodium chloride and Potassium chlorid were purchased from Tianjin Shengao Chemical Reagent Co., Ltd. Methyl orange and Phenolphthalei were supplied from Tianjin Kermel Chemical Reagent Co., Ltd.

\subsection{Characteristics analysis method}

At present, the main methods of water quality analysis are instrumental analysis and chemical analysis. The contents of $\mathrm{Na}^{+}, \mathrm{K}^{+}, \mathrm{Ca}^{2+}, \mathrm{Mg}^{2+}, \mathrm{Ba}^{2+}, \mathrm{Sr}^{2+}, \mathrm{F}^{-}, \mathrm{Cl}^{-}, \mathrm{NO}^{3-}, \mathrm{NO}^{2-}$,

\footnotetext{
*Corresponding author: 807086230@qq.com
} 
$\mathrm{PO}_{4}{ }^{3-}$ and $\mathrm{SO}_{4}{ }^{2-}$ in typical water samples of Jidong Oilfield were determined by ion chromatography. The flow rate controlled by chromatographic conditions was $1.200 \mathrm{~mL} / \mathrm{min}$, and the injection volume was $20 \mathrm{~L}$. The content of $\mathrm{Fe}^{3+}$ in typical water samples of Jidong Oilfield was determined by spectrophotometry. And the contents of $\mathrm{CO}_{3}{ }^{2-}$ and $\mathrm{HCO}_{3}{ }^{-}$in water samples were determined by titration analysis. $0.5 \%$ phenolphthalein solution as indicator, $\mathrm{CO}_{3}{ }^{2-}$ in water samples was determined by sulfuric acid standard solution. $0.1 \%$ methyl orange solution as indicator, $\mathrm{HCO}^{3-}$ in water samples was determined by sulfuric acid standard solution.

\subsection{Preparation of simulated oilfield water}

According to water type and salinity, four typical water samples from Jidong Oilfield were screened out in this experiment, as shown in Table 1.The simulated water is prepared according to the salinity of oilfield water, and the calculation method is based on the calculation program of simulated water (the volume of simulated water is $1 \mathrm{~L}$ ). The preparation of simulated water for four typical Jidong Oilfield water samples are shown in the table below.

Table 1 The preparation of simulated Jidong Oilfield water

\begin{tabular}{ccc}
\hline Name & $\mathrm{Reagent}^{*}$ & Quality $(\mathrm{g})$ \\
\hline & $\mathrm{CaCl}_{2}$ & 1.9680 \\
& $\mathrm{MgCl}_{2} \cdot 6 \mathrm{H}_{2} \mathrm{O}$ & 0.4543 \\
& $\mathrm{NaHCO}_{3}$ & 1.9552 \\
& $\mathrm{Na}_{2} \mathrm{SO}_{4}$ & 0.8220 \\
& $\mathrm{NaCl}$ & 9.4825 \\
& $\mathrm{CaCl}_{2}$ & 10.4373 \\
ND17-1 & $\mathrm{MgCl}_{2} \cdot 6 \mathrm{H}_{2} \mathrm{O}$ & 6.8758 \\
& $\mathrm{NaHCO}_{3}$ & 2.0158 \\
& $\mathrm{Na}_{2} \mathrm{SO}_{4}$ & 0.2029 \\
& $\mathrm{NaCl}$ & 54.7707 \\
& $\mathrm{CaCl}_{2}$ & 1.9645 \\
ND17-3 & $\mathrm{MgCl}_{2} \cdot 6 \mathrm{H}_{2} \mathrm{O}$ & 0.6430 \\
& $\mathrm{NaHCO}_{3}$ & 1.4017 \\
& $\mathrm{Na}_{2} \mathrm{SO}_{4}$ & 0.6950 \\
& $\mathrm{NaCl}$ & 4.6031 \\
& $\mathrm{CaCl}_{2}$ & 0.7417 \\
& $\mathrm{MgCl}_{2} \cdot 6 \mathrm{H}_{2} \mathrm{O}$ & 2.4216 \\
& $\mathrm{NaHCO}_{3}$ & 0.6237 \\
& $\mathrm{Na}_{2} \mathrm{SO}_{4}$ & 0.1609 \\
& $\mathrm{NaCl}$ & 1.1840 \\
\hline
\end{tabular}

\subsection{Synthesis of triazine}

Ethanolamine and formaldehyde were attained at the molar ratio of $1: 1$, ethanolamine was put in a $50 \mathrm{~mL}$ threenecked flask, a small magnet was added in, the threenecked flask was fixed in the magnetic agitator of a constant temperature water bath at $60^{\circ} \mathrm{C}$, the mixed liquid was stirred to add formaldehyde within $0.5 \mathrm{~h}$. Condensation at reflux for $3 \mathrm{~h}$, the synthesized product was cooled to room temperature.

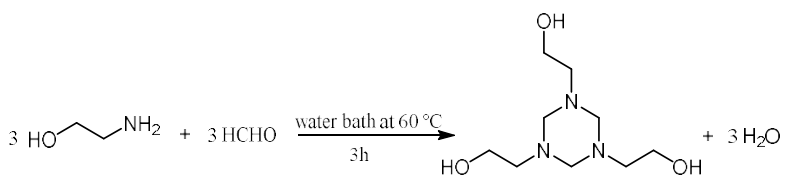

Fig. 1 Synthetic chemical equations for triazine

\subsection{Preparation of corrosive solution}

The preparation of ancient water samples required firstly, 21.65g CaCl $2,1.4 \mathrm{~g} \mathrm{MgCl}_{2} \cdot 6 \mathrm{H}_{2} \mathrm{O}, 0.09 \mathrm{~g} \mathrm{NaHCO}, 1.12 \mathrm{~g}$ $\mathrm{Na}_{2} \mathrm{SO}_{4}, 8.24 \mathrm{~g} \mathrm{NaCl}, 0.9 \mathrm{~g} \mathrm{KCl}$ were weighed and added in beaker, then dissolved with water and determined volume in $1 \mathrm{~L}$ volumetric flask. $100 \mathrm{~mL}$ of ancient water samples were added to $125 \mathrm{~mL}$ grinding bottle, and the triazine products synthesized by ethanolamine and formaldehyde were added, respectively. Ensure that the concentration in water samples was $0,0.1 \%, 0.2 \%, 0.5 \%$, $1.0 \%$, and $2.0 \%$. Corrosion solutions for other types of water sample corrosion inhibitors are prepared in the same manner as described above.

\subsection{Treatment of steel sheets}

The tested material is $A_{3}$ steel sheets were abraded with a series of emery papers, and the surface area $S$ of the steel sheet was calculated and recorded. The steel sheet was successively soaked in petroleum ether and anhydrous ethanol, and then the surface of the steel sheet was dried with a hair dryer. The mass of each steel sheet is weighed by an analytical balance and recorded as $\mathrm{m}_{1}$. Every two pieces of steel discs are divided into a group and photographed for recording. Each group of $A_{3}$ steel sheet was hung with string into the grinding bottles containing corrosion fluids with different corrosion inhibition agents, and these bottles were put into the thermostatic water bath heated to specific temperature in advance for $48 \mathrm{~h}$. The steel sheets were taken out and put on the qualitative filter paper to dry naturally, then photographed for recording. The plates were put in $0.2 \mathrm{~mol} \cdot \mathrm{L}^{-1}$ dilute hydrochloric acid immersed for $30 \mathrm{~s}$, made the steel rust attached to the surface drop out. The liquid on the surface of the steel sheets was blotted up with filter paper, soaked in the petroleum ether for $2 \mathrm{~min}$, immersed in anhydrous ethanol for $2 \mathrm{~min}$. These steel discs were taken out and placed on qualitative filter paper, dried with hair dryer. The quality of each piece of treated steel sheets were weighed by the analytical balance, noted as $\mathrm{m}_{2}$. And compared with the $\mathrm{m}_{1}, \Delta \mathrm{m}$ was obtained.

\subsection{The method of corrosion inhibition performance evaluation}

The weight loss experiments were performed in several kinds of water samples in the absence and presence of various concentration of triazine corrosion inhibitor. The corrosion inhibition performance was mainly evaluated by calculating uniform corrosion rate and corrosion inhibition rate. The mass loss is determined after removing from the corrosion solution. The uniform corrosion rates $\left(W_{\text {corr }}\right)$ have been obtained as suggested in equation (1):

$$
W_{\text {corr }}=\frac{\Delta m}{S t}
$$

$\Delta m$ - the weight loss, $\mathrm{g} ; \mathrm{S}$ - the exposed area of steel sheet, $\mathrm{cm}^{2} ; t$ - the period of immersion of corrosion, $\mathrm{h}$. The inhibition efficiency $\left(E_{w} \%\right)$ was determined by following equation(2): 


$$
E_{w} \%=\frac{\Delta m_{0}-\Delta m}{\Delta m_{0}} \times 100
$$

$\Delta m_{0}$ - the weight loss of the steel sheet in the absence of triazine in the corrosion solution, g; $\Delta m$ - the weight loss of the steel sheet in the presence of triazine, $g$.

\section{Result and Discussion}

\subsection{Water samples analysis results}

The ions in typical water samples of Jidong Oilfield were determined by ion chromatography and chemical analysis. The results are shown in the Table below.

Table 2 The mass concentration of ions in some water samples of Jidong Oilfield

\begin{tabular}{|c|c|c|c|c|c|c|c|c|c|}
\hline \multirow{2}{*}{$\begin{array}{l}\mathrm{N} \\
\mathrm{o} .\end{array}$} & \multirow{2}{*}{ Name } & \multicolumn{5}{|c|}{ Cationic concentration $(\mathrm{mg} / \mathrm{L})$} & \multicolumn{3}{|c|}{$\begin{array}{c}\text { Anion concentration } \\
(\mathrm{mg} / \mathrm{L})\end{array}$} \\
\hline & & $\begin{array}{c}\mathrm{Na}^{+}+ \\
\mathrm{K}^{+}\end{array}$ & $\mathrm{Ca}^{2+}$ & $\mathrm{Mg}^{2}$ & $\begin{array}{c}\mathrm{Ba}^{2+}+ \\
\mathrm{Sr}^{2+}\end{array}$ & $\begin{array}{l}\mathrm{Fe} \\
3+\end{array}$ & $\mathrm{Cl}^{-}$ & $\mathrm{SO}_{2-}$ & $\begin{array}{l}\mathrm{HC} \\
\mathrm{O}_{3}{ }^{-}\end{array}$ \\
\hline 1 & ND8 & $\begin{array}{c}5940 \\
.5\end{array}$ & $\begin{array}{c}319 . \\
2\end{array}$ & 32.9 & 116.9 & 0 & $\begin{array}{c}4014 \\
.9\end{array}$ & $\begin{array}{l}126 \\
3.8\end{array}$ & 336 \\
\hline 2 & ND9 & $\begin{array}{c}7972 \\
.8\end{array}$ & $\begin{array}{c}710 . \\
6\end{array}$ & 54.4 & 98.9 & 0 & $\begin{array}{c}7167 \\
.8\end{array}$ & $\begin{array}{c}555 \\
8\end{array}$ & $\begin{array}{c}142 \\
0\end{array}$ \\
\hline 3 & ND17 & $\begin{array}{c}2063 \\
3.3\end{array}$ & $\begin{array}{c}449 \\
0.2\end{array}$ & $\begin{array}{l}124 \\
0.6\end{array}$ & 285.4 & $\begin{array}{l}1 . \\
2\end{array}$ & $\begin{array}{c}3780 \\
0.3\end{array}$ & $\begin{array}{c}116 . \\
4\end{array}$ & 680 \\
\hline 4 & $\begin{array}{c}\text { ND17 } \\
-1\end{array}$ & $\begin{array}{c}2494 \\
2.1\end{array}$ & $\begin{array}{c}376 \\
8.7\end{array}$ & $\begin{array}{c}823 \\
4\end{array}$ & 203.1 & $\begin{array}{l}2 . \\
9\end{array}$ & $\begin{array}{c}4229 \\
2.3\end{array}$ & $\begin{array}{c}137 . \\
2\end{array}$ & $\begin{array}{c}146 \\
4\end{array}$ \\
\hline 5 & $\begin{array}{c}\text { ND17 } \\
-3\end{array}$ & $\begin{array}{c}4655 \\
.3\end{array}$ & $\begin{array}{c}688 . \\
4\end{array}$ & 77.0 & 3.3 & 0 & $\begin{array}{c}4234 \\
.6\end{array}$ & $\begin{array}{c}469 . \\
9\end{array}$ & $\begin{array}{c}101 \\
8\end{array}$ \\
\hline 6 & ND23 & $\begin{array}{c}4791 \\
.3\end{array}$ & $\begin{array}{c}637 . \\
4\end{array}$ & 38.0 & 70.5 & $\begin{array}{c}0 . \\
1\end{array}$ & $\begin{array}{c}3654 \\
.3\end{array}$ & $\begin{array}{c}724 \\
4\end{array}$ & $\begin{array}{c}118 \\
0\end{array}$ \\
\hline 7 & ND26 & $\begin{array}{c}7203 \\
.9\end{array}$ & $\begin{array}{c}483 . \\
1\end{array}$ & 33.7 & 7.4 & 0 & $\begin{array}{c}1198 \\
4.2\end{array}$ & 0 & 990 \\
\hline 8 & $\begin{array}{l}\text { ND10 } \\
5\end{array}$ & $\begin{array}{c}4807 \\
.5\end{array}$ & $\begin{array}{c}225 . \\
9\end{array}$ & 39.1 & 110.7 & 0 & $\begin{array}{c}4528 \\
.2\end{array}$ & $\begin{array}{c}353 \\
8\end{array}$ & 320 \\
\hline 9 & $\begin{array}{l}\text { ND38 } \\
\text { P1 }\end{array}$ & $\begin{array}{c}1007 \\
.7\end{array}$ & $\begin{array}{c}267 . \\
8\end{array}$ & 2.9 & 11.9 & $\begin{array}{l}0 . \\
7\end{array}$ & $\begin{array}{c}1200 \\
.4\end{array}$ & $\begin{array}{c}108 \\
8\end{array}$ & 453 \\
\hline $\begin{array}{l}1 \\
0\end{array}$ & $\begin{array}{c}\text { ND38 } \\
\text { P64 }\end{array}$ & $\begin{array}{c}3887 \\
7.0\end{array}$ & $\begin{array}{c}817 \\
1.1\end{array}$ & $\begin{array}{c}248 \\
1.8\end{array}$ & $\begin{array}{c}3492 . \\
1\end{array}$ & 0 & $\begin{array}{c}7848 \\
3.2\end{array}$ & $\begin{array}{c}113 . \\
8\end{array}$ & 560 \\
\hline
\end{tabular}

The measured results in Table 2 were processed to calculate the total alkali content, total hardness and salinity of the water sample, and the type of the water sample was determined.

Table 3 Analysis of some water samples in Jidong Oilfield

\begin{tabular}{cccccc}
\hline No. & Name & $\begin{array}{c}\text { Total } \\
\text { base } \\
\text { quantity } \\
(\mathrm{mg} / \mathrm{L})\end{array}$ & $\begin{array}{c}\text { Total } \\
\text { hardness } \\
(\mathrm{mg} / \mathrm{L})\end{array}$ & $\begin{array}{c}\text { Salinity } \\
(\mathrm{mg} / \mathrm{L})\end{array}$ & $\begin{array}{c}\text { Water } \\
\text { type }\end{array}$ \\
\hline 1 & ND8 & 336 & 352.1 & 12024.2 & $\mathrm{NaHCO}_{3}$ \\
2 & ND9 & 1420 & 765 & 17980.3 & $\mathrm{NaHCO}_{3}$ \\
3 & ND17 & 680 & 5730.8 & 65246.1 & $\mathrm{CaCl}_{2}$ \\
4 & ND17-1 & 1464 & 4592.1 & 73633.7 & $\mathrm{CaCl}_{2}$ \\
5 & ND17-3 & 1018 & 765.4 & 11146.5 & $\mathrm{Na}_{2} \mathrm{SO}_{4}$ \\
6 & ND23 & 1180 & 675.4 & 11096.0 & $\mathrm{NaHCO}_{3}$ \\
7 & ND26 & 990 & 516.8 & 20702.3 & $\mathrm{CaCl}_{2}$ \\
8 & ND105 & 320 & 265.0 & 10385.2 & $\mathrm{Na}_{2} \mathrm{SO}_{4}$ \\
9 & ND38P1 & 453 & 270.7 & 3053.2 & $\mathrm{CaCl}_{2}$ \\
10 & ND38P64 & 560 & 10652.9 & 132178.8 & $\mathrm{CaCl}_{2}$ \\
\hline
\end{tabular}

It can be seen from Table 3 that the salinity, hardness and chloride ion content of produced water samples in Jidong Oilfield vary greatly, with the salinity span ranging from thousands to tens of thousands, and the salinity and chloride ions have a great influence on the corrosion rate. Therefore, ND38P1, ND17-3, ND17-1 and ND9 were selected to study the corrosion of steel sheet under different salinity conditions.

\subsection{Evaluation of corrosion inhibition of triazine}

The corrosion inhibition performance of triazine in ancient water quality was evaluated by weight loss method. The results are shown in Table 4. As seen, the uniform corrosion rate decreases with the increase of inhibitor concentration. When the concentration of inhibitor is $2 \%$, the uniform corrosion rate is the lowest $0.0240 \mathrm{~g} \cdot \mathrm{cm}^{-2} \cdot \mathrm{h}^{-1}$. The inhibition efficiency increases to $84.7953 \%$, which has an excellent corrosion inhibition effect on steel sheet.

Table 4 Evaluation of corrosion inhibition of triazine

\begin{tabular}{cccc}
\hline No. & $\begin{array}{c}\text { Inhibitor } \\
\text { concentration(\%) }\end{array}$ & $\begin{array}{c}W_{\text {corr }}\left(\mathrm{g} \cdot \mathrm{cm}^{-}\right. \\
\left.2 \cdot \mathrm{h}^{-1}\right)\end{array}$ & $E_{w} \%$ \\
\hline 1002 & 0.0 & 0.1751 & $/$ \\
1003 & & 0.1789 & \\
1092 & 0.1 & 0.0467 & 72.92 \\
1093 & & 0.0470 & 75.00 \\
1097 & 0.2 & 0.0432 & 75.00 \\
1098 & & 0.0434 & 77.08 \\
1105 & 0.5 & 0.0414 & 76.04 \\
1106 & & 0.0387 & 78.12 \\
1111 & \multirow{2}{*}{1.0} & 0.0340 & 80.21 \\
1112 & & 0.0311 & 82.29 \\
1114 & 2.0 & 0.0269 & 82.46 \\
1115 & & 0.0240 & 84.80 \\
\hline
\end{tabular}

It can be seen from Fig. 2 that the corrosion inhibition effect on the steel sheet is the best when the corrosion inhibitor concentration is $2.0 \%$ at $343 \mathrm{~K}$. The surface of the steel sheet is attached with reddish brown corrosion products, indicating the presence of $\mathrm{Fe}_{3} \mathrm{O}_{4}$. Black corrosion products are also attached to the surface of the steel sheet, and the specific phase composition needs to be further analyzed by XRD. When the concentration of corrosion inhibitor reached more than $0.5 \%$, spot corrosion was observed, mainly because of the uneven adsorption of corrosion inhibitor, a small anode/large cathode activation - passivation battery system is formed $[19,20]$.

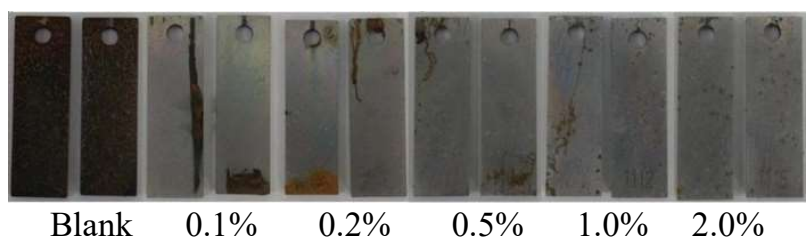

Fig. 2 Comparison of corrosion inhibition effect of different concentrations of triazine

\subsection{Effect of temperature on corrosion inhibition of triazine}

The value of uniform corrosion rate $\left(W_{\text {corr }}\right)$ and inhibition efficiency $\left(E_{w} \%\right)$ were summarized from the weight loss measurements with and without the addition of various concentration of triazine in ancient water at $323 \mathrm{~K}, 333 \mathrm{~K}$, $343 \mathrm{~K}$ and $353 \mathrm{~K}$, respectively. The results were shown in the tables below. 
Table 5 Corrosion inhibition evaluation of triazine at $323 \mathrm{~K}$

\begin{tabular}{cccc}
\hline No. & $\begin{array}{c}\text { Inhibitor } \\
\text { concentration(\%) }\end{array}$ & $\begin{array}{c}W_{\text {corr }}\left(\mathrm{g} \cdot \mathrm{cm}^{-}\right. \\
\left.2 \cdot \mathrm{h}^{-1}\right)\end{array}$ & $E_{w} \%$ \\
\hline 1126 & 0.0 & 0.0840 & $/$ \\
1127 & & 0.0850 & \\
1213 & 0.1 & 0.0144 & 82.42 \\
1214 & & 0.0109 & 86.81 \\
1215 & 0.2 & 0.0111 & 86.81 \\
1216 & & 0.0146 & 82.42 \\
1217 & 0.5 & 0.0091 & 89.01 \\
1218 & & 0.0129 & 84.62 \\
1219 & 1.0 & 0.0109 & 86.81 \\
1220 & & 0.0129 & 84.62 \\
\hline
\end{tabular}

Table 6 Corrosion inhibition evaluation of triazine at 333K

\begin{tabular}{cccc}
\hline No. & $\begin{array}{c}\text { Inhibitor } \\
\text { concentration(\%) }\end{array}$ & $\begin{array}{c}W_{\text {corr }}\left(\mathrm{g} \cdot \mathrm{cm}^{-}\right. \\
\left.2 \cdot \mathrm{h}^{-1}\right)\end{array}$ & $E_{w} \%$ \\
\hline 1181 & 0.0 & 0.1309 & $/$ \\
1182 & & 0.1397 & \\
1123 & 0.1 & 0.0294 & 78.38 \\
1124 & & 0.0256 & 81.08 \\
1125 & 0.2 & 0.0217 & 83.78 \\
1126 & & 0.0255 & 81.08 \\
1127 & 0.5 & 0.0239 & 82.43 \\
1128 & & 0.0201 & 85.14 \\
1129 & 1.0 & 0.0218 & 83.78 \\
1130 & & 0.0220 & 83.78 \\
\hline
\end{tabular}

Table 7 Corrosion inhibition evaluation of triazine at $343 \mathrm{~K}$

\begin{tabular}{cccc}
\hline No. & $\begin{array}{c}\text { Inhibitor } \\
\text { concentration(\%) }\end{array}$ & $\begin{array}{c}W_{\text {corr }}\left(\mathrm{g} \cdot \mathrm{cm}^{-}\right. \\
\left.2 \cdot \mathrm{h}^{-1}\right)\end{array}$ & $E_{w} \%$ \\
\hline 1002 & 0.0 & 0.1751 & $/$ \\
1003 & & 0.1789 & \\
1092 & 0.1 & 0.0467 & 72.92 \\
1093 & & 0.0470 & 75.00 \\
1097 & 0.2 & 0.0432 & 75.00 \\
1098 & & 0.0434 & 77.08 \\
1105 & 0.5 & 0.0414 & 76.04 \\
1106 & & 0.0387 & 78.12 \\
1111 & 1.0 & 0.0340 & 80.21 \\
1112 & & 0.0311 & 82.29 \\
\hline
\end{tabular}

Table 8 Corrosion inhibition evaluation of triazine at $353 \mathrm{~K}$

\begin{tabular}{cccc}
\hline No. & $\begin{array}{c}\text { Inhibitor } \\
\text { concentration(\%) }\end{array}$ & $\begin{array}{c}W_{\text {corr }}\left(\mathrm{g} \cdot \mathrm{cm}^{-}\right. \\
\left.2 \cdot \mathrm{h}^{-1}\right)\end{array}$ & $E_{w} \%$ \\
\hline 1101 & 0.0 & 0.2223 & $/$ \\
1102 & & 0.2259 & \\
1103 & 0.1 & 0.1198 & 46.28 \\
1104 & & 0.1145 & 47.93 \\
1105 & 0.2 & 0.0920 & 58.68 \\
1106 & & 0.0884 & 60.33 \\
1107 & 0.5 & 0.0747 & 66.12 \\
1108 & & 0.0724 & 67.77 \\
1109 & 1.0 & 0.0624 & 71.90 \\
1110 & & 0.0575 & 73.55 \\
\hline
\end{tabular}

The effect of temperature on the inhibition efficiency of triazine was studied in the temperature range from 323 to $353 \mathrm{~K}$. As seen in Table 6 and 7, the corrosion rate in the brine environment is low under the conditions of $323 \mathrm{~K}$ and $333 \mathrm{~K}$, and the addition of $0.1 \%$ triazine can achieve a good corrosion inhibition effect. As the concentration of corrosion inhibitor continues to increase, the corrosion inhibition rate increases in a gentle trend. However, under the temperature of $343 \mathrm{~K}$ and $353 \mathrm{~K}$, the corrosion rate was relatively high while inhibition efficiency was low. And the inhibition efficiency increased slowly as the concentration of triazine increased. Therefore, under the simulated water environment of this brine, the corrosion inhibition requirement could be met by adding $0.1 \%$ corrosion inhibitor at low temperature, while the corrosion inhibition rate could reach $82.29 \%$ only when the concentration of triazine was $1.0 \%$ at high temperature.

\subsection{Effects of ions in produced water on corrosion inhibition performance}

The water samples were chosen as ND38P1, ND17-3, ND17-1 and ND9 by weight loss method to study the corrosion of steel sheet under different salinity conditions at $323 \mathrm{~K}$

Table 9 Evaluation of corrosion inhibition of triazine in different typical water samples

\begin{tabular}{ccccc}
\hline Name & No. & $\begin{array}{c}\text { Inhibitor } \\
\text { concentration(\%) }\end{array}$ & $\begin{array}{c}W_{\text {corr }} \\
\left(\mathrm{g} \cdot \mathrm{cm}^{-}\right. \\
\left.2 \cdot \mathrm{h}^{-1}\right)\end{array}$ & $E_{w} \%$ \\
\hline ND38P1 & 14 & 0 & 0.1976 & $/$ \\
& 1075 & & 0.2202 & \\
& 1076 & 2.0 & 0.0152 & 92.89 \\
& 1078 & & 0.0114 & 94.67 \\
ND17-3 & 1079 & 0 & 0.2336 & $/$ \\
& 15 & & 0.2183 & \\
& 1093 & 2.0 & 0.0501 & 95.59 \\
& 16 & & 0.0420 & 96.70 \\
ND17-1 & 1117 & 0 & 0.1343 & $/$ \\
& 17 & & 0.1535 & \\
& 1121 & 2.0 & 0.0072 & 94.94 \\
ND9 & 18 & & 0.0036 & 97.47 \\
& 1123 & 0 & 0.1635 & $/$ \\
& 1124 & 2.0 & 0.1511 & \\
& 1125 & 2.0 & 0.0223 & 86.05 \\
& & & 0.0205 & 87.21 \\
\hline
\end{tabular}

It can be seen from Table 9 that the corrosion rate of steel sheet is different in different water quality environments. After comparison in the same environment, it is found that the corrosion rate of steel sheet is lower in water quality of $\mathrm{CaCl}_{2}$ and $\mathrm{NaHCO}_{3}$ than in water quality of $\mathrm{NaSO}_{4}$. The water quality is less than $75000 \mathrm{mgL}^{-1}$, and the corrosion inhibitor can have better corrosion inhibition effect. The inhibition efficiency is all above $85 \%$, which can be applied to the water quality system of oil field to delay the corrosion of steel pipe. 


\section{Conclusion}

The corrosion inhibition effect of triazine on steel sheet was efficient. The inhibition effect was the best when the concentration was $2.0 \%$, and the inhibition efficiency was up to $84.80 \%$. The corrosion rate decreased with the increase of inhibitor concentration and the inhibition efficiency increased with the increase of inhibitor concentration. Some produced water samples in Jidong Oilfield have high salinity and high hardness, which is easy to cause steel pipe scaling and aggravating corrosion. The results showed that when the salinity reached tens of thousands, the corrosion rate increased significantly, and the appropriate addition of triazine corrosion inhibitor had obvious corrosion inhibition effect, with the inhibition efficiency above $85 \%$.

\section{References}

1. Igunn E.T., Chen G.Z., Produced water treatment technologies. International Journal of Low-Carbon Technologies, 9(3) (2014) 157-177.

2. Malvis A., Hodaifa G., Halioui M., Seyedsalehi M., Sánchez S., Integrated process for olive oil mill wastewater treatment and its revalorization through the generation of high added value algal biomass. Water research, 151 (2019) 332-342.

3. Yang M., Jing B., Chen W., Li Q., Yin X., Experimental study on COD composition and electrochemical degradation of waste water in offshore oilfields. Journal of the Chinese Chemical Society, 64(1) (2017) 73-79.

4. Zhou Z.F., Wang M.X., Zuo X.H., Yao Y.H., Comparative investigation of bacterial, fungal, and archaeal community structures in soils in a typical oilfield in Jianghan, China. Archives of environmental contamination and toxicology, 72(1) (2017) 65-77.

5. Fischer K., Ferreira F.C., Holzberg B.B., Pastor J.S., Reinli L., Furuie R., Dutra T.A. Integrated modeling of formation damage and multiple induced hydraulic fractures during produced water reinjection. In SPE Latin America and Caribbean Petroleum Engineering Conference. Society of Petroleum Engineers.(2017, May)

6. Azari A., Nazemi S., Kakavandi B., Rastgar A., Survey of scaling and corrosion potential in drinking water resources of Shahrood city by using stability indexes in 2013, (2016).

7. Chen T., Chang F., Liang F., Mukhles A., Corrosion and Scaling Monitoring Under Real Downhole Conditions in Sour Gas Wells. In SPE Kingdom of Saudi Arabia Annual Technical Symposium and Exhibition. Society of Petroleum Engineers, (2018, August).

8. Askari M., Aliofkhazraei M., Ghaffari S., Hajizadeh A., Film former corrosion inhibitors for oil and gas pipelines-A technical review. Journal of Natural Gas Science and Engineering, 58 (2018) 92-114.
9. Andrei M., Ghiban B., Rucai V., Bacterial activity in a deposit from a residual injection water pipeline. REVISTA DE CHIMIE, 70(8) (2019) 2707-2711.

10. Gavrilenko N.A., Volgina T.N., Urazov E.V., Gavrilenko M.A., Transparent polymer sensor for visual and photometrical detection of thiocyanate in oilfield water. Journal of Petroleum Science and Engineering, 172 (2019) 960-963.

11. Liang S.C., A new technique for oil field water analysis by ion chromatography. China petroleum and chemical industry standard and quality, 14 (2013) 25-27.

12. Zou Y.P., Application of water ion chromatography in liaohe oilfield. Logging engineering, 19(1) (2008) 9-13.

13. Liu Y., Zhang Y., Yuan J. Influence of produced water with high salinity and corrosion inhibitors on the corrosion of water injection pipe in Tuha oil field. Engineering Failure Analysis, 45 (2014) 225233.

14. [14]Li H.J., Zhang W., Wu Y.C., Anti-Corrosive Properties of Alkaloids on Metals. In Alkaloids-Their Importance in Nature and Human Life. IntechOpen, (2018)

15. Dehghani A., Bahlakeh G., Ramezanzadeh B., Ramezanzadeh M., Detailed macro-/micro-scale exploration of the excellent active corrosion inhibition of a novel environmentally friendly green inhibitor for carbon steel in acidic environments. Journal of the Taiwan Institute of Chemical Engineers, 100 (2019) 239-261.

16. Verma C., Kumar A.M., Mazumder M.A.J., Quraishi,M.A., Chitosan-Based Green and Sustainable Corrosion Inhibitors for Carbon Steel. Chitin-Chitosan: Myriad Functionalities in Science and Technology, 143 (2018).

17. Qian P.P., Wang S., Feng K.R., Ren Y.J., Molecular modeling studies of 1,2, 4-triazine derivatives as novel h-DAAO inhibitors by 3D-QSAR, docking and dynamics simulations. RSC advances, 8(26) (2018) 14311-14327.

18. Obot I.B., Kaya S., Kaya C., Tüzün B., Theoretical evaluation of triazine derivatives as steel corrosion inhibitors: DFT and Monte Carlo simulation approaches. Research on Chemical Intermediates, 42(5) (2016) 4963-4983.

19. Park I.C., Kim S.J., Effect of stabilizer concentration on the cavitation erosion resistance characteristics of the electroless nickel plated gray cast iron in seawater. Surface and Coatings Technology, 376 (2019) 31-37.

20. Du Y., Gao L.Y., Yu D., Liu Z.Q., Comparison and mechanism of electromigration reliability between $\mathrm{Cu}$ wire and $\mathrm{Au}$ wire bonding in molding state. Journal of Materials Science: Materials in Electronics, (2020) 1-9. 